\title{
Longpath DOAS observations of surface BrO at Summit, Greenland
}

\author{
J. Stutz ${ }^{1}$, J. L. Thomas ${ }^{1}$, S. C. Hurlock ${ }^{1}$, M. Schneider ${ }^{1}$, R. von Glasow ${ }^{2}$, M. Piot ${ }^{3}$, K. Gorham ${ }^{4}$, J. F. Burkhart , $^{5}$, \\ L. Ziemba ${ }^{6,7}$, J. E. Dibb ${ }^{6}$, and B. L. Lefer ${ }^{8}$ \\ ${ }^{1}$ University of California, Los Angeles; Department of Atmospheric and Oceanic Sciences, Los Angeles, CA 90095, USA \\ ${ }^{2}$ School of Environmental Sciences, University of East Anglia, Norwich, UK \\ ${ }^{3}$ EnBW Trading, Karlsruhe, Germany \\ ${ }^{4}$ University of California Irvine; School of Physical Sciences, Irvine, USA \\ ${ }^{5}$ Norwegian Institute for Air Research (NILU), Kjeller, Norway \\ ${ }^{6}$ Institute for the Study of Earth, Oceans and Space, University of New Hampshire, Durham, New Hampshire, USA \\ ${ }^{7}$ NASA Langley Research Center, Hampton, VA, 23681, USA \\ ${ }^{8}$ Earth and Atmospheric Sciences Department, University of Houston, Houston, TX, USA
}

Received: 24 January 2011 - Published in Atmos. Chem. Phys. Discuss.: 25 February 2011

Revised: 14 September 2011 - Accepted: 14 September 2011 - Published: 27 September 2011

\begin{abstract}
Reactive halogens, and in particular bromine oxide $(\mathrm{BrO})$, have frequently been observed in regions with large halide reservoirs, for example during bromine catalyzed coastal polar ozone depletion events. Much less is known about the presence and impact of reactive halogens in areas without obvious halide reservoirs, such as the polar ice sheets or continental snow.
\end{abstract}

We report the first LP-DOAS measurements of $\mathrm{BrO}$ at Summit research station in the center of the Greenland ice sheet at an altitude of $3200 \mathrm{~m}$. BrO mixing ratios in May 2007 and June 2008 were typically between $1-3 \mathrm{pmol} \mathrm{mol}^{-1}$, with maxima of up to $5 \mathrm{pmol} \mathrm{mol}^{-1}$. These measurements unequivocally show that halogen chemistry is occurring in the remote Arctic, far from known bromine reservoirs, such as the ocean. During periods when FLEXPART retroplumes show that airmasses resided on the Greenland ice sheet for 3 or more days, $\mathrm{BrO}$ exhibits a clear diurnal variation, with peak mixing ratios of up to $3 \mathrm{pmol} \mathrm{mol}^{-1}$ in the morning and at night. The diurnal cycle of $\mathrm{BrO}$ can be explained by a changing boundary layer height combined with photochemical formation of reactive bromine driven by solar radiation at the snow surface. The shallow stable boundary layer in the morning and night leads to an accumulation of $\mathrm{BrO}$ at the surface, leading to elevated $\mathrm{BrO}$ despite the expected smaller release from the snowpack during these times of low solar radiation. During the day when photolytic formation of reac-

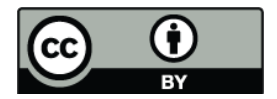

Correspondence to: J. Stutz

(jochen@atmos.ucla.edu) tive bromine is expected to be highest, efficient mixing into a deeper neutral boundary layer leads to lower $\mathrm{BrO}$ mixing ratios than during mornings and nights.

The extended period of contact with the Greenland snowpack combined with the diurnal profile of $\mathrm{BrO}$, modulated by boundary layer height, suggests that photochemistry in the snow is a significant source of $\mathrm{BrO}$ measured at Summit during the 2008 experiment. In addition, a rapid transport event on 4 July 2008, during which marine air from the Greenland east coast was rapidly transported to Summit, led to enhanced mixing ratios of $\mathrm{BrO}$ and a number of marine tracers. However, rapid transport of marine air from the Greenland east coast is rare and most likely not the main source of bromide in surface snow at Summit. The observed levels of $\mathrm{BrO}$ are predicted to influence $\mathrm{NO}_{\mathrm{x}}$ chemistry as well as impact $\mathrm{HO}_{\mathrm{x}}$ partitioning. However, impact of local snow photochemistry on $\mathrm{HO}_{\mathrm{x}}$ is smaller than previously suggested for Summit.

\section{Introduction}

The presence of reactive halogens and their impact on boundary layer chemistry has been well documented in the coastal Arctic and Antarctic (e.g. Barrie et al., 1988; Hausmann and Platt, 1994; Tuckermann et al., 1997; Saiz-Lopez et al., 2007) as well as lower latitudes (e.g. Saiz-Lopez et al., 2004; Peters et al., 2005; Read et al., 2008; Osthoff et al., 2008). Reactive halogen chemistry has also been observed near surface salt deposits, i.e. salt lakes and salt pans (e.g. Hebestreit et al., 1999; Stutz et al., 2002). All of these observations were made

Published by Copernicus Publications on behalf of the European Geosciences Union. 
close to abundant sources of halides which, through multiphase chemical or biological processes, are released into the gas-phase as reactive halogen species.

Much less is known about the presence and impact of halogen species at locations where no clear halide reservoir exists. Recent observations of $\mathrm{ClNO}_{2}$ in Boulder (Thornton et al., 2010) point to the presence of halogens in the continental urban boundary layer. A number of studies have also found mixing ratios of bromine oxide of up to $3 \mathrm{pmol} \mathrm{mol}^{-1}=3 \mathrm{ppt}$ (for the remainder of the manuscript we will use ppt as the equivalent of $\mathrm{pmol} \mathrm{mol}^{-1}$ ), in the free troposphere (e.g. Fitzenberger et al., 2000; Theys et al., 2007; Salawitch et al., 2010). A recent study by Sjostedt et al. (2007) proposed the presence of reactive bromine at Summit, Greenland, to explain the discrepancy between observed $\mathrm{OH}$ concentrations and those calculated by a highly constrained box model. Summit is located on top of the Greenland ice sheet at $3200 \mathrm{~m}$ altitude and, with a distance of at least $400 \mathrm{~km}$ from the nearest ocean, removed from large halogen sources. Small amounts of chloride and bromide are found in surface snow at Summit (see Dibb et al., 2010), but it is to date unclear if reactive gaseous halogens are present at sufficiently high levels to have an influence on atmospheric chemistry.

Even at low levels, reactive halogen species can impact gas-phase atmospheric chemistry (von Glasow and Crutzen, 2007; Stutz et al., 1999). Chlorine, and to a lesser extent bromine, are atmospheric oxidants. In particular, bromine oxide is well known to catalytically destroy tropospheric ozone. BrO mixing ratios above 5-10 ppt lead to ozone destruction predominantly proceeding through the self reaction of $\mathrm{BrO}$ or reactions of $\mathrm{BrO}$ with $\mathrm{ClO}$ and $\mathrm{IO}$, followed by a recycling of the halogen atom or molecule reaction product (von Glasow and Crutzen, 2007). At BrO mixing ratios below $5 \mathrm{ppt}$ the dominant destruction path is the formation and photolysis of $\mathrm{HOBr}$ :

$$
\begin{aligned}
& \mathrm{BrO}+\mathrm{HO}_{2} \longrightarrow \mathrm{HOBr}+\mathrm{O}_{2} \\
& \mathrm{HOBr}+h v \longrightarrow \mathrm{OH}+\mathrm{Br} \\
& \mathrm{Br}+\mathrm{O}_{3} \longrightarrow \mathrm{BrO}+\mathrm{O}_{2}
\end{aligned}
$$

An equivalent cycle occurs for iodine (von Glasow and Crutzen, 2007). Together with Reaction (R3), Reactions (R1-R2) form a catalytic cycle that converts $\mathrm{HO}_{2}$ to $\mathrm{OH}$, thus impacting $\mathrm{HO}_{\mathrm{x}}$ chemistry. $\mathrm{HOBr}$ formed in Reaction (R1) is also important for the release of gaseous $\mathrm{Br}_{2}$ from aqueous and surface bromide (von Glasow and Crutzen, 2007). This autocatalytic activation process, often referred to as "bromine explosion", is believed to be the main formation mechanism of reactive gaseous bromine in the presence of halide reservoirs. $\mathrm{BrO}$ also impacts the pseudo steady state of $\mathrm{NO}$ and $\mathrm{NO}_{2}$ (Reaction $\left.\mathrm{R} 4\right)$ :

$\mathrm{BrO}+\mathrm{NO} \longrightarrow \mathrm{Br}+\mathrm{NO}_{2}$
Through the change in $\mathrm{OH} / \mathrm{HO}_{2}$ and $\mathrm{NO}_{2} / \mathrm{NO}$ ratios, $\mathrm{BrO}$ indirectly influences the oxidative power of the atmosphere (Chameides and Davis, 1980; Stutz et al., 1999; von Glasow et al., 2004). Finally, reactive bromine, i.e. $\mathrm{Br}$ and $\mathrm{BrO}$, is known to oxidize gaseous elemental mercury (GEM) to a more reactive form of gaseous mercury (RGM), which can then be rapidly removed from the atmosphere (Schroeder et al., 1998; Brooks et al., 2011).

Motivated by the results of Sjostedt et al. (2007), we performed LP-DOAS measurements of $\mathrm{BrO}$ at Summit Station, on the Greenland ice sheet, in May/June 2007 and June/July 2008, as part of the collaborative Greenland Summit Halogen- $\mathrm{HO}_{\mathrm{x}}$ experiment (GSHOx). The main focus of the work presented here was to determine the levels of $\mathrm{BrO}$ in the remote boundary layer at Summit and their possible impact on atmospheric chemistry. We are also interested in determining the possible sources of reactive bromine in the boundary layer, and in particular the question of whether there is a release of reactive bromine from the snowpack and if transport from the ocean occurs.

\section{Experimental}

Two field camapaigns were performed within the GSHOx project at Summit research station, in the center of the Greenland ice sheet $\left(72^{\circ} \mathrm{N}, 38^{\circ} \mathrm{W}, 3200 \mathrm{~m}\right.$ a.s.l.). In 2007 observations of various trace gases and meteorological parameters were made from 14 May to 15 June 2007. The 2008 experiment was performed later in the year, from 9 June to 8 July 2008 (see GSHOx special issue in ACP).

As part of the suite of GSHOx observations, we measured $\mathrm{BrO}$, ozone, and other trace gases by long-path Differential Optical Absorption Spectroscopy (LP-DOAS) (Platt and Stutz, 2008) during both experiments. The LP-DOAS instrument consists of a double coaxial Newtonian telescope, which is used to send collimated light from a Xe-arc lamp onto an array of quartz corner cube retroreflectors. The light returning from the retroreflectors is collected by the telescope and analyzed using the DOAS technique. The multichannel scanning technique (MCST) (Platt and Stutz, 2008) was used to record and assemble the final absorption spectra.

The LP-DOAS telescope was set up in a wooden shelter on the snow surface at Summit station. Retroreflectors were mounted at $2 \mathrm{~m}$ and $3 \mathrm{~m}$ height at a distance of $2 \mathrm{~km}$ and 5/4 km (2007/2008), respectively (Fig. 1). Retroreflectors, and thus the absorption paths, were selected according to visibility and refractive turbulence effects at Summit. Ancillary measurements were performed at Satellite (Sat)-camp and the science tower/temporary atmospheric watch observatory (TAWO).

The absorption spectra recorded by the LP-DOAS instrument were analyzed using a combination of a linear and nonlinear least squares fit, as previously described in detail in (Tuckermann et al., 1997; Stutz et al., 2002; Platt and Stutz, 


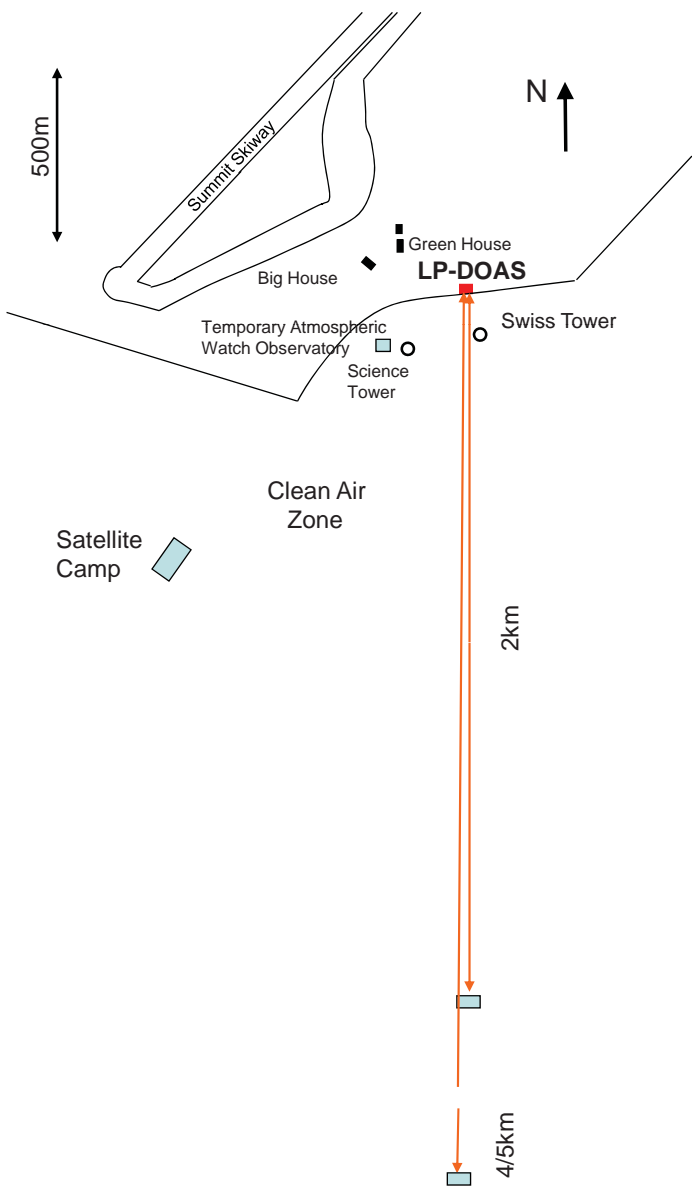

Fig. 1. Overview of the LP-DOAS setup during GSHOx.

2008). Absorption cross sections of $\mathrm{O}_{3}, \mathrm{BrO}, \mathrm{HCHO}$, and $\mathrm{O}_{4}$ (Voigt et al., 2001; Fleischmann et al., 2004; Cantrell et al., 1990; Greenblatt et al., 1990) adapted to the instrument resolution, a Xe lamp spectrum, and a polynomial of degree 7 were fitted to the atmospheric spectrum. $\mathrm{BrO}$ was analyzed in the wavelength range from $332 \mathrm{~nm}$ to $351 \mathrm{~nm}$. To minimize the influence of Xe emissions lines from our lamp and possible $\mathrm{HCHO}$ absorptions we excluded two wavelength intervals (338.7-342.3 nm and 346.1-347.4 nm) from our analysis. Statistical errors of the $\mathrm{BrO}$ mixing ratio were determined by the retrieval procedure, and are reported here as $1 \sigma$ statistical errors. It should be noted that the error varies due to visibility and possible changes in the instrument performance, as well as the choice of light path. The systematic errors of the reported $\mathrm{BrO}$ and $\mathrm{O}_{3}$ mixing ratios are dominated by the uncertainties of the absorption cross sections of 4-7\% and 10\%, respectively (Voigt et al., 2001; Fleischmann et al., 2004). The BrO detection limit, i.e. twice the $1 \sigma$ statistical error determined by the fit for each spectrum, was in the range of $0.6-2.2 \mathrm{ppt}$ for the $2 \mathrm{~km}$ path and $0.3-2.3 \mathrm{ppt}$ for the $4 / 5 \mathrm{~km}$ path. The lower limit of these ranges reflect the performance limit of the instrument and the path length,

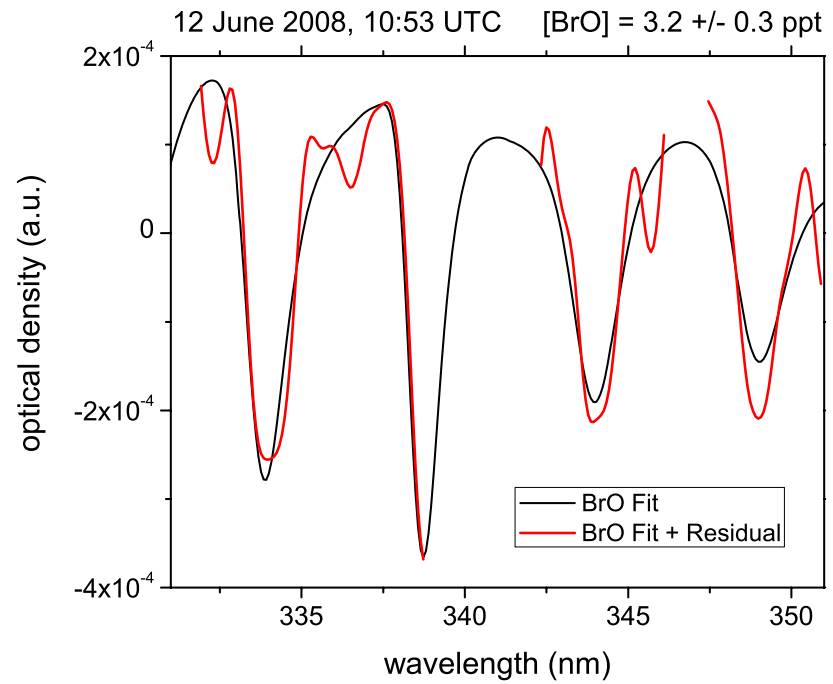

Fig. 2. Comparison of the $\mathrm{BrO}$ absorption structure in an atmospheric spectrum after removing the absorptions of ozone, $\mathrm{HCHO}$, and $\mathrm{O}_{4}$ with a $\mathrm{BrO}$ reference spectrum (Fleischmann et al., 2004). The spectral regions from $338.7-342.3 \mathrm{~nm}$ and $346.1-347.4 \mathrm{~nm}$ were excluded from the fit to reduce interferences due to instrumental effects.

i.e. the detection limit on the longer light path is half of that on the shorter light path. The upper end of the detection limit is due to photon noise limitations, which is less influenced by path length. Differential absorptions of $\mathrm{BrO}$ were clearly identified in many absorption spectra acquired at Summit in both years (see Fig. 2 for a 2008 example), demonstrating unequivocally the presence of $\mathrm{BrO}$ at Summit.

Visibility was impacted by a number of environmental factors and sometimes limited operation of the LP-DOAS. During times of winds with speeds above $10 \mathrm{~m} \mathrm{~s}^{-1}$ blowing snow reduced the visibility to the extent that light could not be transmitted over either light path. The frequent surface temperature inversions (see below) caused fluctuations in the refractive index of air and thus the aim onto the retroreflectors on a timescale of $1-5 \mathrm{~min}$. In 2007 this led to a loss of signal which made the measurements impossible during these times. A laser aiming system was developed in 2008 that compensated for this effect and allowed measurements during times with modestly fluctuating air refractive indices. However, at Summit ground inversions often also lead to ground fog which reduced the visibility below $1 \mathrm{~km}$, preventing the LP-DOAS from taking measurements during fog events. Consequently the LP-DOAS dataset has numerous gaps, which have to be considered in the interpretation, in particular with respect to possible biases due the ground inversions, fog, and blowing snow. In addition, it should be noted that the $2 \mathrm{~km}$ path was typically chosen in the presence of fog and snow, while the $4 / 5 \mathrm{~km}$ path was only used during periods of good visibility. 

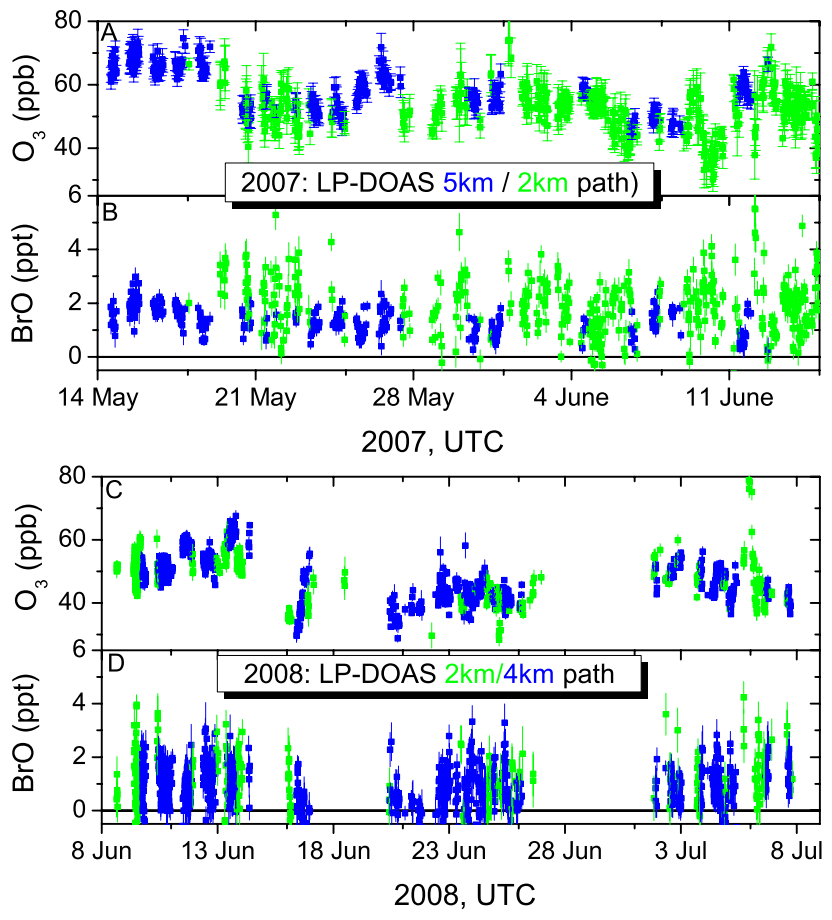

Fig. 3. Overview of the 2007 and 2008 GSHOx BrO and ozone data measured by the LP-DOAS on either the $2 \mathrm{~km}$ (green) or $5 \mathrm{~km} / 4 \mathrm{~km}$ (blue) light paths. A laser aiming system used in 2008 resulted in longer periods of measurements in 2008 vs. 2007. In both years storms with high wind speeds and nocturnal fog resulted in periods without data.

Measurements of $\mathrm{BrO}$ were also performed by Chemical Ionization Mass spectrometry (Liao et al., 2011a,b; Thomas et al., 2011b). Levels of $\mathrm{BrO}$ were similar to those observed by our LP-DOAS system. Meteorological observations were performed by NOAA/ESRL/GMD at the science tower/TAWO (data courtesy of Mefford, 2010). These measurements include wind speed and direction, as well as atmospheric temperature $2 \mathrm{~m}$ and $10 \mathrm{~m}$ above the surface (Herbert et al., 1986; Conway et al., 2010). Other observations performed by $\mathrm{GSHO}_{\mathrm{x}}$ collaborators are presented in this special issue.

\section{Results}

Measurements of $\mathrm{BrO}$ and ozone were performed from 14 May-15 June 2007 and 9 June-8 July 2008 (Fig. 3). Ozone mixing ratios in 2007 mainly varied between $40-60 \mathrm{nmol} \mathrm{mol}^{-1}=40-60 \mathrm{ppb}$ (for the remainder of the manuscript we will use ppb as the equivalent of nmol mol${ }^{-1}$ ), with a period of 60-70 ppb during the first week of the experiment. Ozone mixing ratios in 2008 were somewhat lower, with of $40-65 \mathrm{ppb}$ during the first week of the experiment and 35-65 ppb during the last week of the experiment (with the exception of one peak of $\approx 80 \mathrm{ppb}$ on 6 July). In the mid-
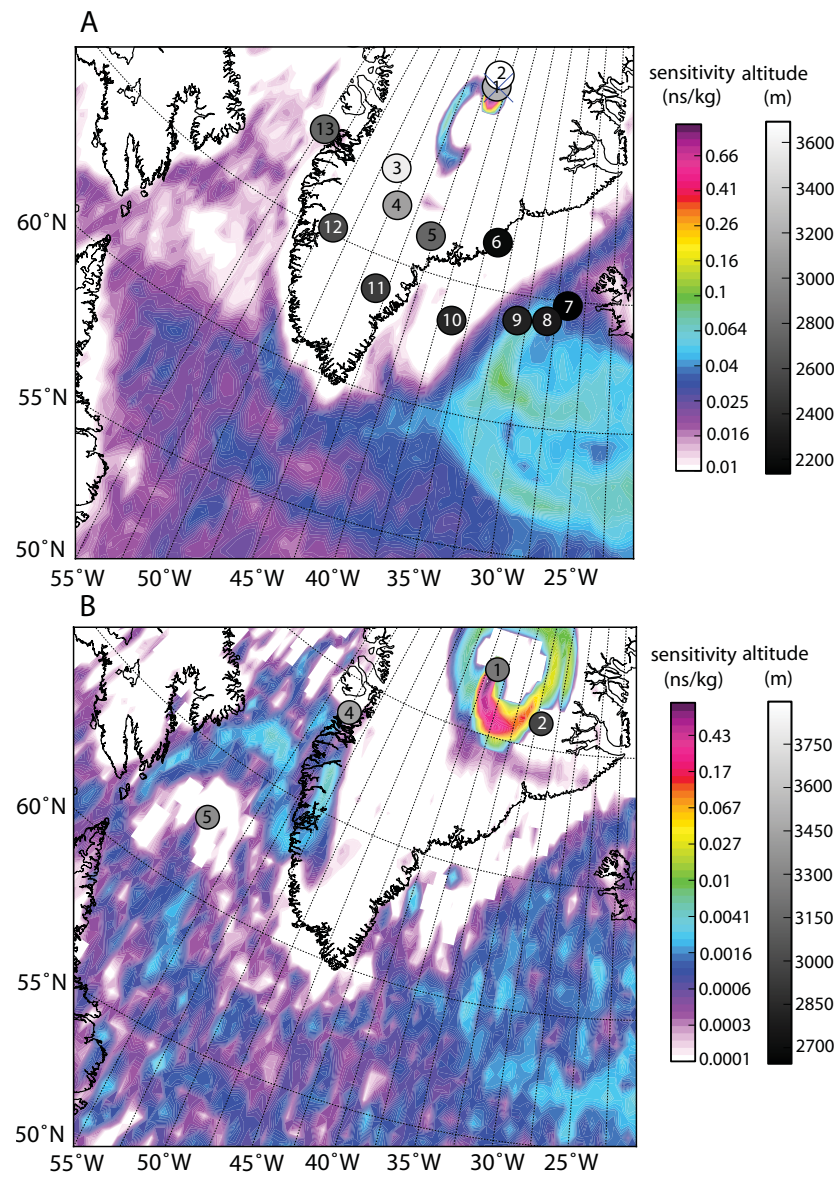

Fig. 4. Footprint emissions sensitivity for the period of 10 (A) and 12 (B) June 2008, 00:00-03:00 UTC, using the nested model output $\left(0.5^{\circ}\right)$. The release location (Summit Station) is marked with an "X". The retroplume centroid locations for each day back are shown as gray circles, where the shade of gray is scaled to elevation. On 10 June 2008, days 1, 2, and 3 are clearly located over the Greenland ice sheet. On 12 June 2008 only days 1 and 2 are visible, with day 3 being further north over the Greenland Ice Sheet. Note the enhanced sensitivity in the lowest model layer recirculating around Summit.

dle two weeks of the experiment $\mathrm{O}_{3}$ was between 30-50 ppb. During both years substantial variations in ozone mixing ratios were observed, most likely due to airmass changes.

BrO mixing ratios in 2007 were 1-3 ppt during 14-19 May 2007 and 23-26 May 2007 and up to 5 ppt during other periods (Fig. 3). In general, $\mathrm{BrO}$ mixing ratios measured on the $2 \mathrm{~km}$ light path were higher than those measured on the $5 \mathrm{~km}$ light path. The reason for the difference between the two light paths in 2007 is unclear. Tests during times of good visibility revealed no clear bias above the error of each measurement. Comparisons at times of low visibility, when the shorter light path was exclusively used, could not be performed. It is thus possible, although unlikely, that the lower visibility lead to an instrument bias. One can also speculate that other reasons could lead to higher atmospheric 
$\mathrm{BrO}$ levels during times of low visibility. The two conditions under which the shorter light path was used were fog and refractive index fluctuations caused by extremely strong surface inversions. In the case of fog events the increased aerosol surface area could lead to a more efficient heterogeneous bromine recycling and thus higher $\mathrm{BrO}$ mixing ratios. Similarly, shallow boundary layers could lead to an accumulation of gaseous bromine released from the snow into the lowest meters of the atmosphere and thus to higher $\mathrm{BrO}$ levels. Both of these scenarios will be discussed in more detail in Sect. 4. Ultimately we cannot derive a conclusive explanation of the difference in $\mathrm{BrO}$ concentrations on the two light path in 2007.

The 2007 BrO mixing ratios in Fig. 3 somtimes show rapid variations. Part of this variability can be attributed to the statistical errors in the measurements, as shown by the error bars in the figure. Frequent gaps in the data will also lead to discontinuities that appear as fast changes in the mixing ratios. Finally, some of these changes may be attributed to airmass changes. An example of such a rapid airmass change will be discussed in Sect. 4.2.

$\mathrm{BrO}$ mixing ratios were somewhat lower in 2008 , with maxima in the range of 3-4 ppt. Again, measurements on the shorter light path appear to be higher than those on the $4 \mathrm{~km}$ light path, although the difference is not as pronounced as in 2007. This could be, in part, due to the laser aiming system used in 2008, which allowed the LP-DOAS system to operate on the longer path during a larger portion of each day than in 2007.

Using FLEXPART, a Lagrangian Particle Dispersion Model (LPDM) (Stohl et al., 2002), we evaluated the origin of air masses observed during the measurement periods and the potenital for sources of gas-phase bromine. Specifically, we have tried to identify periods during which air resided on the Greenland ice sheet for at least 3 days before arriving at Summit in order to investigate if $\mathrm{BrO}$ could potentially be released locally from photochemical reaction in snow, rather than through transport of bromine rich air masses to Summit.

In Fig. 4 we show the FLEXPART footprint sensitivities for two cases where the air mass recirculated over the Greenland ice sheet prior to our measurements. Footprint emission sensitivities provide a source-receptor relationship for air arriving at Summit. They are a measure of the residence time of the air in the retroplume in the lowest $100 \mathrm{~m}$ of a model grid cell (in units of $\mathrm{ns} \mathrm{kg}^{-1}$ ) (Stohl et al., 2002; Hirdman et al., 2010). Footprint emission sensitivities are thus ideally suited to illustrate contact of airmasses with the surface and potential surface sources during the time before arrival at Summit. The centroid locations are calculated from a cluster analysis of the 60000 released particles. The location represents the geographic centroid of all the particles. The centroid location of the particle retroplume is gray-shaded by altitude, and shows the air mass remained fairly close to the surface of the Greenland ice sheet for the days prior to reaching the station. Based on this analysis we identified one

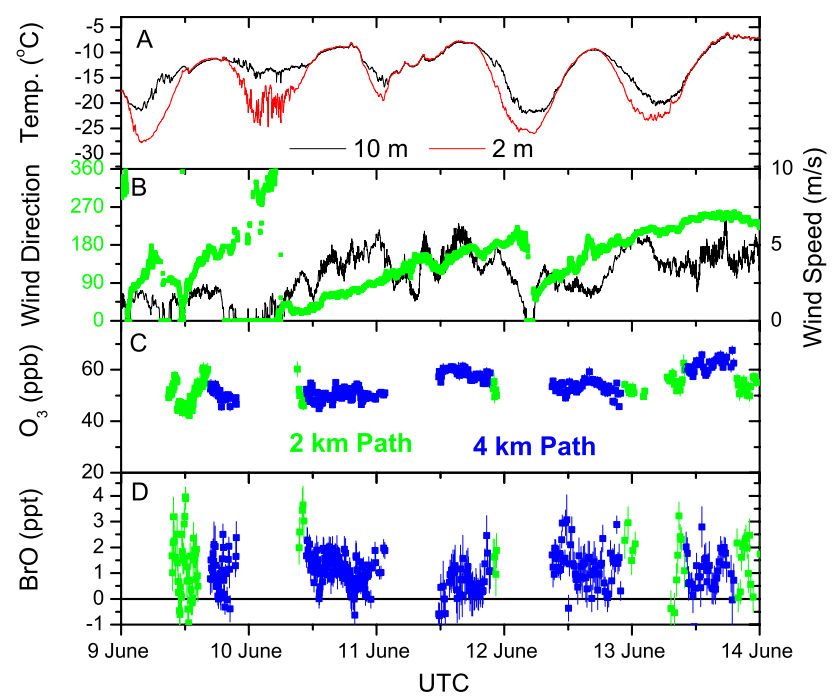

Fig. 5. Period of local airmasses during the beginning of the 2008 GSHOx experiment. Strong temperature gradients between $2 \mathrm{~m}$ and $10 \mathrm{~m}$ altitude (A) and low wind speeds (B) were observed at night during this period. Ozone mixing ratios $(\mathbf{C})$ showed little variability, while $\mathrm{BrO}$ (D) varied between $0-5$ ppt. The gaps in LP-DOAS data at night are due to the reduced visibility in the presence of ground fog.

period in 2007 (14-19 May 2007) and two periods in 2008 (9-14 June 2008 and 23-26 June 2008) that are characterized by residence times of more than 2 days near the surface of the Greenland ice sheet. Figure 5 shows an overview of the meteorology and LP-DOAS measurements during the first of these local airmass periods in 2008 . Wind speeds were generally low between $0-5 \mathrm{~m} \mathrm{~s}^{-1}$ and temperatures varied between $-25^{\circ} \mathrm{C}$ and $-27^{\circ} \mathrm{C}$ at night and $-10^{\circ} \mathrm{C}$ and $-7^{\circ} \mathrm{C}$ during the day. Surface temperature inversions were encountered at night, which were accompanied by ground fog at night and in the early morning. The sky during this period was generally clear with occasional high clouds. Solar zenith angles varied between $85^{\circ}$ and $50^{\circ}$, and photolysis rates varied approximately by a factor of 10 between local midnight and noon (Thomas et al., 2011a). Ozone mixing ratios were between 50-60 ppb and showed little temporal variation, except on 9 June 2008. The $\mathrm{BrO}$ mixing ratios showed values up to $4 \mathrm{ppt}$, which were predominantly observed in the early morning.

\section{Discussion}

Our observations clearly confirm the presence of $\mathrm{BrO}$ at Summit during times when air was on the Greenland ice sheet, and not in contact with any well known bromide reservoirs, for several days. In the following section we will further explore these periods with local airmasses, to investigate the potential origin of reactive bromine at Summit. We will 

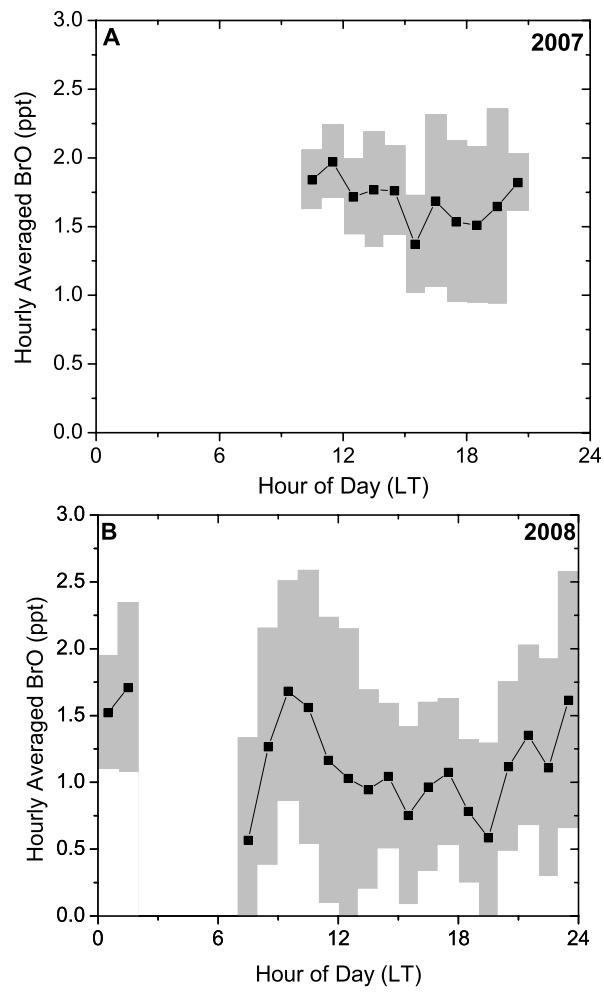

Fig. 6. Hourly averaged $\mathrm{BrO}$ mixing ratios for time periods with local airmasses in 2007 (A) and 2008 (B). Please note that time is given in local time.

also discuss an event of rapid transport of marine air to Summit.

\subsection{Local airmasses}

To further study the diurnal behavior and compare $\mathrm{BrO}$ levels between 2007 and 2008, we calculated hourly averaged $\mathrm{BrO}$ mixing ratios for the 2007 period with local air masses from 14-19 May 2007 (Fig. 6a) and the 2008 periods with local air between 9-14 June 2008 and 23-26 June 2008 (Fig. 6b). We only report averages that were calculated based on 5 or more data points. Hourly averaging serves to reduce the statistical error of the measurements as well as atmospheric day-to-day variability in the data. The scarcity of nighttime and early morning data only allowed averaging between 10:00 LT and 21:00 LT (LT $=$ UTC $-2 \mathrm{~h}$ ) in 2007, and between 00:00-01:00 LT and 08:00-23:00 LT in 2008.

A comparison of the averaged data shows that the 2007 daytime $\mathrm{BrO}$ mixing ratios were around $1.5-2 \mathrm{ppt}$, while the 2008 mixing ratios were between $0.7-1.2 \mathrm{ppt}$. Considering that the backtrajectories in 2007 and 2008 were similar, this difference is surprising. The decrease in $\mathrm{BrO}$ between the 2007 and 2008 GSHOx campaigns confirms the results of Dibb et al. (2010), who observed a decrease of soluble gasphase bromide between the two experiments. Dibb et al.
(2010) speculate that the observed lower bromide levels in the snow in 2008 compared to 2007 could explain lower gasphase bromine. However, the reason for lower bromine in the snow-air system in 2008 compared to 2007 is not clear. Possible explanations include the time of year that the measurements were taken, or the relatively lower daytime temperatures of $-20^{\circ} \mathrm{C}$ to $-40^{\circ} \mathrm{C}$ in 2007 compared to $-7^{\circ} \mathrm{C}$ to $-27^{\circ} \mathrm{C}$ in 2008 . More longterm measurements are needed to determine if the observed seasonal difference between 2007 and 2008 is a common phenomenon.

It is difficult to discern a diurnal profile in 2007 due to the lack of morning, evening, and nighttime data, when the operation of the LP-DOAS was not possible. It appears that there is a small decrease in mixing ratios between 12:00 and 18:00 $(\approx 1.5 \mathrm{ppt})$ compared to the late morning and early evening data $(\approx 1.8 \mathrm{ppt})$. The 2008 data shows a similar behavior in this time period, but at lower absolute $\mathrm{BrO}$ levels, as discussed above. In 2008 the use of a laser aiming system allowed data acquisition during a much larger part of the day, thus resulting in better $24 \mathrm{~h}$ data coverage. The expanded diurnal data in 2008 reveals a much clearer temporal profile of $\mathrm{BrO}$, with a peak in the morning, followed by a general decrease towards 20:00 LT, and another peak around midnight. This behavior is at first surprising, as in prior observations $\mathrm{BrO}$ diurnal profiles often show larger mixing ratios during mid-day, when solar radiation is strongest, than during night and the morning and evening transition periods (for example Read et al., 2008).

We hypothesize that the observed diurnal profile is caused by two competing effects: boundary layer evolution and photochemistry. Like many snow covered environments, Summit often encounters strong shallow surface inversions. At night, when solar heating is small, these inversions are often only 20-30 m deep (Thomas et al., 2011a). Increased solar heating in the morning leads to a breakup of these inversions and a transition to a well-mixed daytime boundary layer of 200-300 m depth. The concentration of any trace gas formed at the surface or in the snow and mixed within the boundary layer will thus be strongly modulated by the boundary layer height (BLH). At Summit the volume into which this trace gas is mixed increases at least tenfold from the night and early morning to the afternoon. Consequently, for a constant surface source of gas-phase inorganic bromine an inverse dependence of bromine mixing ratios on the BLH would be expected.

Tethered balloon profiles in 2008 do not have sufficient temporal coverage. Therefore we use the temperature gradient between $2 \mathrm{~m}$ and $10 \mathrm{~m}$ as a proxy for vertical stability and BLH. Our simplified assumption is that BLH is inversely proportional to the temperature gradient, i.e. lower temperatures at the surface than aloft are indicative of shallow boundary layers, while zero or negative temperature gradients represent well mixed boundary layers. To test our hypothesis of bromine formation in snow and to determine the impact of $\mathrm{BLH}$, we correlated the 2008 hourly averaged $\mathrm{BrO}$ mixing 
ratios, as a proxy for inorganic bromine, (Fig. 6b) with the hourly averaged $10 \mathrm{~m}-2 \mathrm{~m}$ temperature gradient in Fig. 7a. A weak linear correlation between these two parameters, with a coefficient of $R^{2}=0.53$, is apparent. The correlation is dominated by the morning period (08:00-12:00 LT) when the boundary layer breaks up and temperature gradients disappear, as well as after 19:00 LT when the boundary layer forms again.

While it appears that the $\mathrm{BLH}$ modulates $\mathrm{BrO}$ and inorganic gas-phase bromine, the correlation is not very strong as the surface source of gas-phase bromine is not constant in time. Model calculations by Thomas et al. (2011a) show that the most likely source of gas-phase reactive bromine in the boundary layer at Summit is its formation in the snow/firn. Modeled gas-phase mixing ratios of inorganic bromine species, such as $\mathrm{BrO}, \mathrm{Br}_{2}$ and $\mathrm{BrNO}_{3}$, in the snow/firn follow solar radiation and peak at local noon. The dominant source of boundary layer $\mathrm{BrO}$ is the transport of $\mathrm{Br}_{2}$ and $\mathrm{BrNO}_{3}$ out of the snow into the atmosphere, followed by their photolysis and the reaction of $\mathrm{Br}$ with ozone.

It is difficult to find a detailed functional description of these processes based on the field measurements alone, but in a first approximation one can assume that the atmospheric $\mathrm{BrO}$ source is proportional to the actinic flux. We will use the $\mathrm{NO}_{2}$ photolysis rate measured during GSHOx (see Thomas et al., 2011a, for the raw data) as a proxy for actinic flux and expand our previous correlation analysis, assuming that the photochemical source of $\mathrm{BrO}$ is proportional to $J\left(\mathrm{NO}_{2}\right)$. We then combine the dependence of surface $\mathrm{BrO}$ mixing ratios on BLH with the temperature gradient as a proxy, with $J\left(\mathrm{NO}_{2}\right)$ as a proxy for the $\mathrm{BrO}$ source, to propose the following simplified dependence of $\mathrm{BrO}$ mixing ratios: [BrO] $\propto(T(10 \mathrm{~m})-T(2 \mathrm{~m})) \cdot J\left(\mathrm{NO}_{2}\right)$. Figure $7 \mathrm{~b}$ shows the correlation of $(T(10 \mathrm{~m})-T(2 \mathrm{~m})) \cdot J\left(\mathrm{NO}_{2}\right)$ with hourly averaged $\mathrm{BrO}$ mixing ratios. The correlation coefficient of $R^{2}=0.69$ is higher than that of the temperature gradient alone, showing that inclusion of a photochemical bromine source improves the functional description of the observed diurnal profile of BrO.

While our correlation analysis is obviously not conclusive, we propose that local photolytic formation of reactive bromine at the surface, and most likely in the snow and firn, explains the $\mathrm{BrO}$ measured by our LP-DOAS. While the amount of $\mathrm{BrO}$ released is driven by solar radiation, the concentration is additionally modulated by the boundary layer height, leading to a dilution of $\mathrm{BrO}$ when the boundary layer grows in the morning. These two factors together lead to a diurnal profile, with a morning and evening peak when the boundary layer is shallow but sufficient actinic flux is available. The accompanying paper by (Thomas et al., 2011a), confirms this interpretation using a more detailed analysis with a 1-D chemistry and transport model.

It should be mentioned that the formation of fog during the morning and the evening could serve as an additional factor enhancing $\mathrm{BrO}$, as the recycling of inorganic bromine
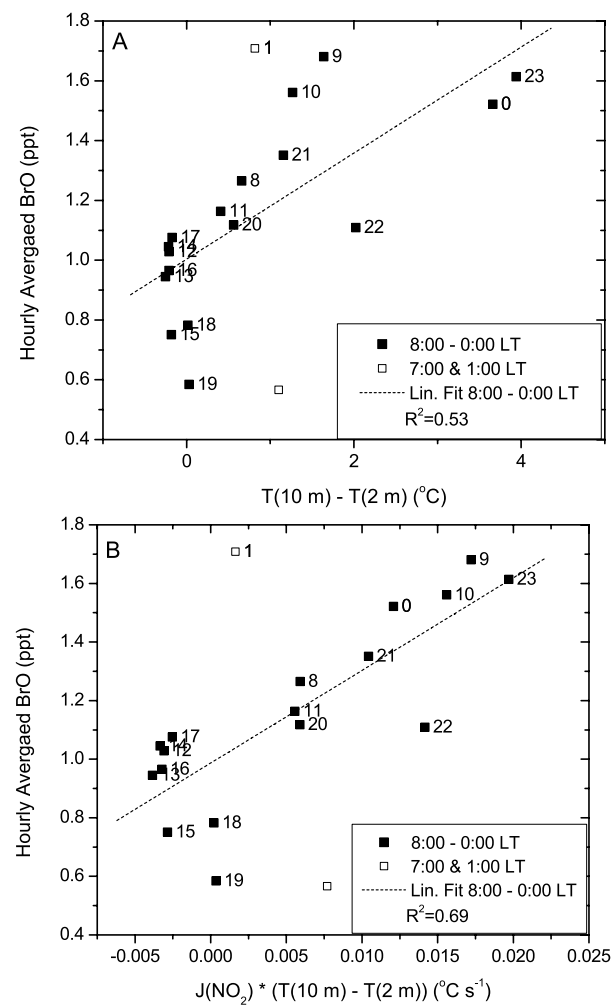

Fig. 7. Correlation of hourly averaged $\mathrm{BrO}$ mixing ratios for local air masses during the 2008 experiment with the temperature gradient as a proxy of vertical stability (A) and the product of the temperature gradient and the $\mathrm{NO}_{2}$ photolysis rate $J\left(\mathrm{NO}_{2}\right)(\mathbf{B})$. Only data from 08:00 LT to 0:00 LT is considered in the analysis. The $\mathrm{BrO}$ average for 07:00 LT and 01:00 LT was based on too few data points to be representative and, although shown in the figure, was not included in the correlation analysis. Labels denote the hour of the day.

through $\mathrm{HOBr}$ uptake on fog particles and conversion to $\mathrm{Br}_{2}$ could lead to higher reactive bromine levels in the boundary layer. As $\mathrm{HOBr}$ recycling to $\mathrm{Br}_{2}$ also depends on the actinic flux (through the availability of $\mathrm{HO}_{2}$ and the photolysis of $\mathrm{Br}_{2}$ ) and the $\mathrm{BLH}$ (due to the surface cooling required to form this fog), it is difficult to distinguish it in our correlation analysis. However, we believe that this effect is of smaller magnitude than reactive bromine formation in snow and dilution. This interpretation is also supported by model calculations by Thomas et al. (2011a), which do not require fog to describe the observed diurnal profile of $\mathrm{BrO}$.

\subsection{Marine airmasses}

While the $\mathrm{BrO}$ observations indicate that reactive bromine is locally formed on the Greenland ice sheet, it is not clear how bromine or bromide is initially transported to the center of the Greenland ice sheet to an altitude of $3200 \mathrm{~m}$. The closest source of bromide is the ocean around Greenland and 

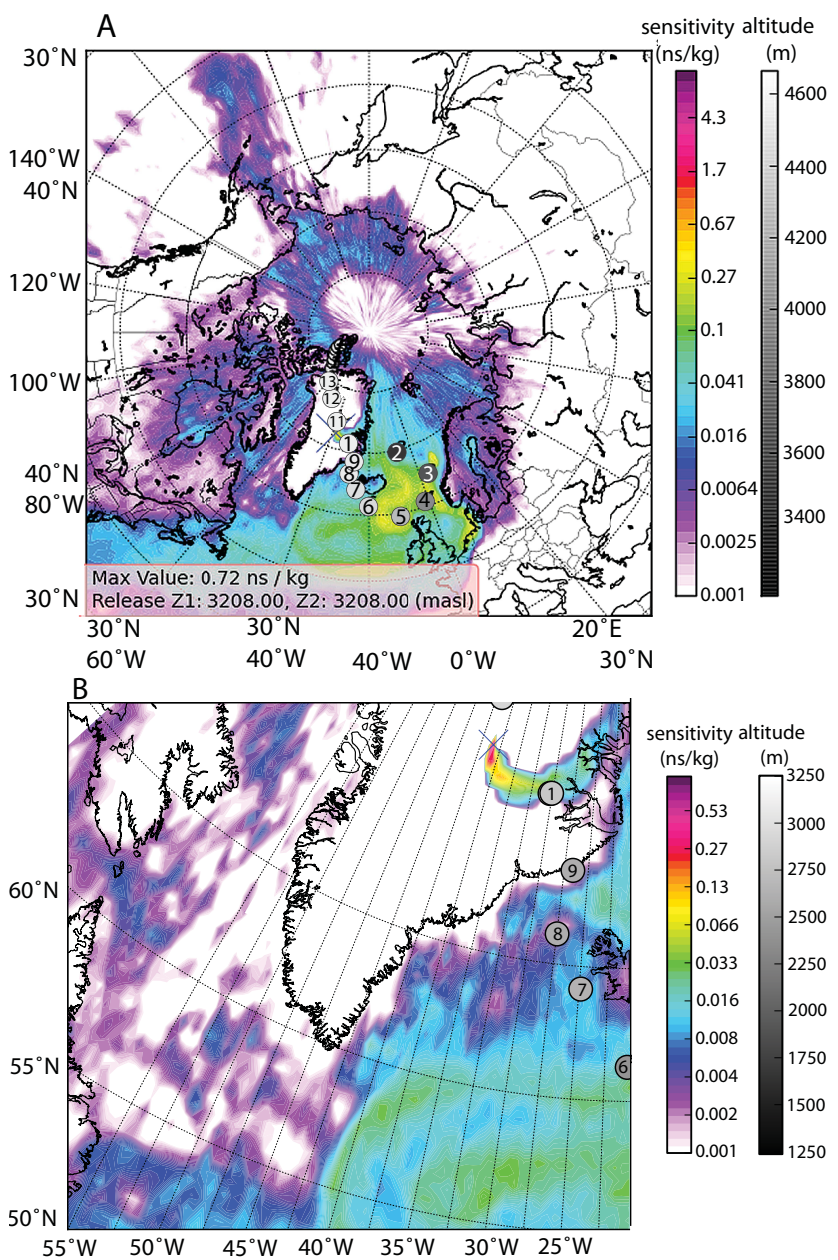

Fig. 8. Footprint emissions sensitivity for 4 July 2008, 12:0015:00 UTC using the global model output $\left(1^{\circ}\right)$. The release location (Summit Station) is marked with an " $\mathrm{X}$ ". The retroplume centroid locations for each day back are shown as gray circles, where the shade of gray is scaled to elevation. Air ariving at Summit Station during this period clearly originated from the North Atlantic and was at the Greenland coast less that $24 \mathrm{~h}$ earlier. Both panels show the same data with different spatial resolution.

one can speculate that air rapidly transported from the marine boundary layer could deliver bromide to the surface at Summit.

Our analysis of the FLEXPART retroplumes indicates that air masses having clear marine origin were rare during our campaigns. Most air masses, if not local, were transported to Summit in the free troposphere, at altitudes above the boundary layer, and having limited contact with continents or oceans prior to reaching the station. However, on 4 July 2008 an air mass with origin on the East coast of Greenland was rapidly transported to Summit in less than $24 \mathrm{~h}$ (Fig. 8). The windspeed measured at Summit at noon was $\approx 6.5 \mathrm{~m} \mathrm{~s}^{-1}$. The wind direction was fairly constant at $\approx 120^{\circ}$. Based on the distance to the coast and the windspeed, a transport time

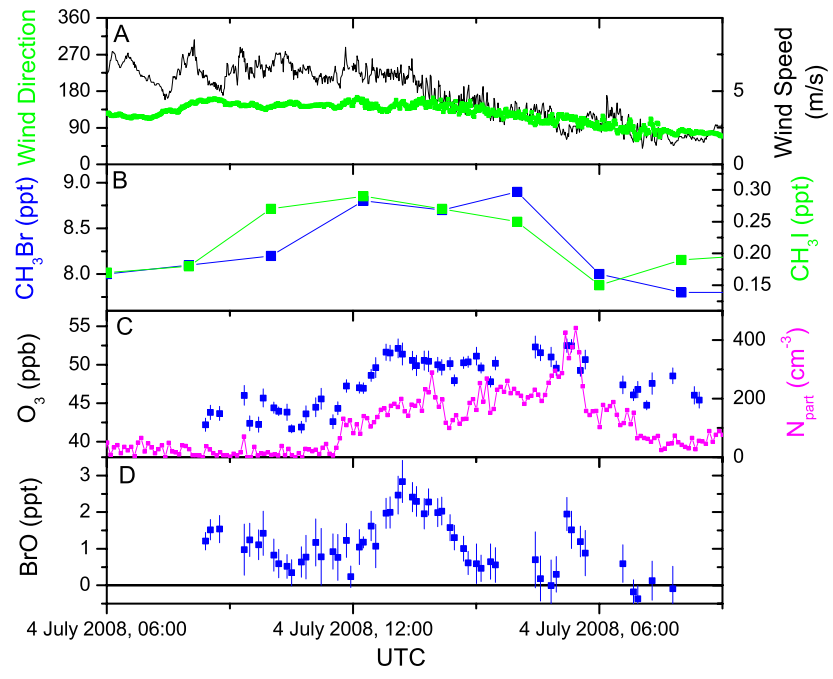

Fig. 9. Example case of a marine airmass, as indicated by the FLEXPART retroplume, arriving at Summit at 12:00 UTC on 4 July 2008. Wind direction and speed (A) showed a slow turn from $120^{\circ}$ to $80^{\circ}$ and a slow decrease, respectively. $\mathrm{CH}_{3} \mathrm{Br}$ and $\mathrm{CH}_{3} \mathrm{I}(\mathbf{B})$ as well as particle number and ozone $(\mathbf{C})$ were increased from noon to 18:00 UTC compared to their morning levels. BrO mixing ratios (D) showed an simultaneous increase from $0-1 \mathrm{ppt}$ in the morning to a maximum of $2.8 \pm 0.6 \mathrm{ppt}$ at 13:12 UTC.

of $\approx 24 \mathrm{~h}$ can be derived, in agreement with the FLEXPART retroplume. Furthermore, the FLEXPART footprint sensitivity plots for this period show the air mass was circulating in the North Atlantic sector and had enhanced exposure to the marine boundary layer prior to arriving at Summit, making it likely this air mass was directly influenced by the ocean.

Further evidence for oceanic influence can be found in the mixing ratios of $\mathrm{CH}_{3} \mathrm{Br}$ and $\mathrm{CH}_{3} \mathrm{I}$ (Fig. 9), both of which are predominantly of oceanic origin (see Colman et al., 2001; Swanson et al., 2002, for details on the measurements principle). Mixing ratios of both species are elevated from noon to 18:00 UTC. It is unclear why the $\mathrm{CH}_{3} \mathrm{I}$ mixing ratio appears to increase earlier than that of $\mathrm{CH}_{3} \mathrm{Br}$. Other evidence for an airmass change around noon is the increase of ozone mixing ratios from $45 \mathrm{ppb}$ to $52 \mathrm{ppb}$, and an increase of particle numbers observed by a CPC (Ziemba et al., 2010). Surface snow samples taken at 13:45 UTC on 4 July 2008 (Dibb et al., 2010) also show an increase of chloride, sodium, and bromide (not shown). From the combination of observations at Summit and the results from the FLEXPART model, it seems clear that the air of marine origin arrived at Summit between noon and 18:00 UTC on 4 July 2008.

BrO on 4 July 2008 was around 1 ppt before 12:00 UTC, i.e. levels that were typical for Summit (Fig. 5). After 12:00 UTC BrO slowly increased, simultaneously with $\mathrm{O}_{3}$ and particle number concentration, as the airmass changed. A maximum of $2.8 \pm 0.6 \mathrm{ppt}$ was observed at 13:12 UTC. $\mathrm{BrO}$ then decreased, reaching $0.5 \mathrm{ppt}$ around 15:00 UTC. 
Table 1. Surface snow bromide concentrations at different distances from the skiway at Summit in 2008 (see also Fig. 1). No dependence of surface $\mathrm{Br}^{-}$concentrations on distance to the skiway or station (approximately between runway and satellite camp) was found. Please refer to Dibb et al. (2010) for details on the sampling and analytical procedure.

\begin{tabular}{|c|c|c|c|}
\hline Locations & Date & $\begin{array}{l}\text { Approximate Distance } \\
\text { from Skiway }(\mathrm{km})\end{array}$ & $\begin{array}{l}\text { Surface Snow Br } \\
\quad\left(\mathrm{nmoll}^{-1}\right)\end{array}$ \\
\hline Skiway & 1 July 2008 & 0 & $7.1 \pm 1.3^{* *}$ \\
\hline \multirow{3}{*}{ Satellite Camp } & 9 June 2008 & 1 & $7.2 \pm 0.1^{*}$ \\
\hline & 17 June 2008 & 1 & $7.3 \pm 2.3^{*}$ \\
\hline & 20 June 2008 & 1 & $7.1 \pm 1.3^{* *}$ \\
\hline Clean Air Zone & 17 June 2008 & 1.4 & $8.3 \pm 1.74^{*}$ \\
\hline $2 \mathrm{~km}$ Retroreflector & 9 June 2008 & 2.5 & $8.3 \pm 0.82^{*}$ \\
\hline 5 km Retroreflector*** & 9 June 2008 & 5.5 & $7.3 \pm 1.41^{*}$ \\
\hline
\end{tabular}

* error calculated as the standard deviation of three surface snow samples at the same location; ** error determined from average of the standard deviations of the errors of the other samples; ${ }^{* * *}$ location of 2007 retroreflector tower

Another peak of $\mathrm{BrO}$ was observed at 17:12 UTC. This peak in $\mathrm{BrO}$ was again accompanied by an increase in $\mathrm{O}_{3}$ and particle number concentration. It is currently unclear why ozone increased during this time period, as one would generally expect smaller mixing ratios over the North Atlantic. A possible explanation is anthropogenic influence on the air mass 3-5 days prior to arrival at Summit, as indicated by the FLEXPART footprint sensitivity analysis (Fig. 8).

The 4 July 2008 example is interesting, as the trajectory (Fig. 8) resembles that presented by Sjostedt et al. (2007) during a period of high $\mathrm{OH}$ which could not be explained by their box model calculations. While 3 ppt of BrO observed in 2008 is insufficient (see Sect. 5) to explain the discrepancy between measured and modeled $\mathrm{OH}$ in Sjostedt et al. (2007), it shows that it is possible to transport reactive bromine from the marine boundary layer to Summit.

\section{Conclusions}

The observation of $\mathrm{BrO}$ at Summit Greenland is somewhat surprising, as the amount of bromide available in this environment is small. Our analysis is consistent with the results of Dibb et al. (2010), who also concluded that bromide in the snow is photochemically activated and released into the boundary layer. The levels of $\mathrm{BrO}$ from this mechanism are modulated by the actinic flux and the diurnal evolution of the boundary layer. We investigate this mechanism in more detail in two accompanying modeling papers (Thomas et al., 2011a,b).

Possible sources include bromide in falling snow, or transport and deposition of inorganic or organic bromine species from the free troposphere or marine regions around Greenland. Summit station and aircraft operation at Summit have been excluded as possible sources of bromine based on a comparison of snow samples collected close to these possible sources, with samples collected at 0.0-5.5 km distance from the skiway and the station (Table 1).

Rapid transport from the north Atlantic was observed during at least one rapid marine transport event in 2008, showing clearly that gaseous bromine species can, at times, be transported directly from the Greenland east-coast to Summit in late Spring and Summer. A trajectory study by Kahl et al. (1997) shows that this type of trajectory is rare $(2-4 \%$ of annual trajectories). It thus appears that the observed type of rapid transport event is infrequent and that these events are unlikely to contribute significantly to the bromide budget at Summit. It is unclear how important marine influence is during other times of the year. Transport of air with low ozone associated with bromine catalyzed arctic ozone depletion events has been found to influence Summit in spring (Hirdman et al., 2010). While it is likely that these transport events bring gaseous bromine or aerosol bromide to Summit, we have no clear evidence that this is the main source of snow bromide observed at Summit. Our observations also show that boundary layer chemistry is significantly different during these marine transport events from times when air resides on the Greenland ice sheet for extended periods of time. Other possible factors influencing bromine chemistry at Summit are the frequent fog and blowing snow events. Our LP-DOAS was not able to measure during these events, but one can speculate that bromine recycling on the ice particle surfaces can alter the partitioning between the various inorganic bromine species. Further studies of bromine chemistry in the presence of ice particles would be desirable, as ice particles at Summit can serve as a model for ice clouds in the upper troposphere.

An interesting question arising from our observations is what impact the low levels of BrO have on boundary layer chemistry over a snow surface. While a detailed analysis 
requires the use of a 1-D model (Thomas et al., 2011a), we can make simplified pseudo steady state calculations to derive an estimate on how $\mathrm{HO}_{\mathrm{x}}$ and $\mathrm{NO}_{\mathrm{x}}$ chemistry is changed in the presence of 2-5 ppt of $\mathrm{BrO}$ at Summit. The cycling of $\mathrm{NO}$ and $\mathrm{NO}_{2}$ is largely dominated by the reactions of $\mathrm{NO}$ with $\mathrm{O}_{3}$ and $\mathrm{HO}_{2}$, forming $\mathrm{NO}_{2}$, as well as the photolysis of $\mathrm{NO}_{2}$ to $\mathrm{NO}+\mathrm{O}$. One can thus write the Leighton Ratio, i.e. $\left[\mathrm{NO}_{2}\right] /[\mathrm{NO}]$ as follows:

$L_{\mathrm{BrO}}=\frac{\left[\mathrm{NO}_{2}\right]}{[\mathrm{NO}]}$
$=\frac{k_{\mathrm{NO}+\mathrm{O}_{3}} \cdot\left[\mathrm{O}_{3}\right]+k_{\mathrm{NO}+\mathrm{HO}_{2}} \cdot\left[\mathrm{HO}_{2}\right]+k_{\mathrm{NO}+\mathrm{BrO}} \cdot[\mathrm{BrO}]}{J_{\mathrm{NO}_{2}}}$

The levels of ozone during most of the experiment were fairly constant, with an average of $55 \mathrm{ppb} . \mathrm{HO}_{2}$ and $J\left(\mathrm{NO}_{2}\right)$ show clear diurnal variations, both following the actinic flux. Noontime and morning $\mathrm{HO}_{2}$ concentrations during the experiment were roughly $5 \times 10^{8} \mathrm{~cm}^{-3}$, and $3 \times 10^{8} \mathrm{~cm}^{-3}$, respectively (Liao et al., 2011b). Based on Eq. (1) we can find an expression for the change in $L_{\mathrm{BrO}}$ with and without $\mathrm{BrO}$, which is independent of $J\left(\mathrm{NO}_{2}\right)$ :

$$
\frac{L_{\mathrm{BrO}}}{L_{\mathrm{noBrO}}}=1+\frac{k_{\mathrm{NO}+\mathrm{BrO}} \cdot[\mathrm{BrO}]}{k_{\mathrm{NO}+\mathrm{O}_{3}} \cdot\left[\mathrm{O}_{3}\right]+k_{\mathrm{NO}+\mathrm{HO}_{2}} \cdot\left[\mathrm{HO}_{2}\right]}
$$

During noon time the presence of 2 ppt of $\mathrm{BrO}$ increases the Leighton ratio by $\approx 7 \%$. The influence is somewhat higher, with $\approx 20 \%$ increase in the morning when $\mathrm{HO}_{2}$ is lower and $\mathrm{BrO}$ is around $5 \mathrm{ppt}$. In summary, this analysis indicates that $\mathrm{BrO}$ shifts the steady state of gas-phase $\mathrm{NO}_{\mathrm{x}}$ from $\mathrm{NO}$ to $\mathrm{NO}_{2}$. It should also be noted here that $\mathrm{NO}_{\mathrm{x}}$ and bromine chemistry are linked through reactions occurring in the snow liquid layer and the aerosol, which have not been considered in our simplified calculations.

A similar approximation can be used for the change in the $\mathrm{OH} / \mathrm{HO}_{2}$ ratio in the presence of $\mathrm{BrO}$ by assuming that the two most important reactions determining the partitioning between $\mathrm{OH}$ and $\mathrm{HO}_{2}$ are the reactions of $\mathrm{HO}_{2}+\mathrm{NO} \longrightarrow$ $\mathrm{OH}+\mathrm{NO}_{2}$ and the reaction of $\mathrm{OH}$ with $\mathrm{CO}$ forming $\mathrm{HO}_{2}$. $\mathrm{BrO}$ impacts this ratio by providing an additional pathway through the formation and photolysis of $\mathrm{HOBr}$. Assuming that $\mathrm{HOBr}$ is in a pseudo steady state, one can approximate the $\mathrm{OH} / \mathrm{HO}_{2}$ ratio by:

$H_{\mathrm{BrO}}=\frac{[\mathrm{OH}]}{\left[\mathrm{HO}_{2}\right]}=\frac{k_{\mathrm{NO}+\mathrm{HO}_{2}} \cdot[\mathrm{NO}]+k_{\mathrm{HO}_{2}+\mathrm{BrO}} \cdot[\mathrm{BrO}]}{k_{\mathrm{CO}+\mathrm{OH}} \cdot[\mathrm{CO}]}$

The change in this ratio due to $\mathrm{BrO}$ can be approximated by:

$$
\frac{H_{\mathrm{BrO}}}{H_{\mathrm{noBrO}}}=1+\frac{k_{\mathrm{HO}_{2}+\mathrm{BrO}} \cdot[\mathrm{BrO}]}{k_{\mathrm{NO}+\mathrm{HO}_{2}} \cdot[\mathrm{NO}]}
$$

The impact of $\mathrm{BrO}$ is thus dependent on the levels of NO. In the presence of a constant NO mixing ratio of $20 \mathrm{ppt}, 2 \mathrm{ppt}$ of $\mathrm{BrO}$ would lead to an increase of this ratio by $\approx 25 \%$, while 5 ppt of $\mathrm{BrO}$ will increase the ratio by $\approx 61 \%$. However, because $\mathrm{NO}$ mixing ratios are also lower in the presence of $\mathrm{BrO}$ (assuming constant $\left[\mathrm{NO}_{\mathrm{x}}\right]$ and using Eq. (2)), the impact of $\mathrm{BrO}$ on $\mathrm{OH} / \mathrm{HO}_{2}$ is overestimated if $[\mathrm{NO}]$ is assumed to be constant. A better representation of $\mathrm{NO}$ in Eq. (4) can be obtained from Eq. (2) by assuming a constant $\mathrm{NO}_{\mathrm{x}}$ mixing ratio of $200 \mathrm{ppt}$ and ignoring the indirect dependence of NO on $\mathrm{BrO}$ through $\mathrm{HO}_{2}$. This results in a somewhat smaller estimated increase of the $\mathrm{OH} / \mathrm{HO}_{2}$ ratio of $\approx 20 \%$ in the presence of $2 \mathrm{ppt} \mathrm{BrO}$ and $\approx 50 \%$ in the presence of 5 ppt of $\mathrm{BrO}$. The detailed model study by Thomas et al. (2011b) finds a similar value for the increase of $\mathrm{OH} / \mathrm{HO}_{2}$ in the presence of 2 ppt of $\mathrm{BrO}$ of $\approx 15 \%$, confirming our simplified calculation. While we have, on occasion, observed 5 ppt of $\mathrm{BrO}$ at Summit, these levels are never sustained throughout the day. It is thus unlikely that the persistent factor of two or more disagreement between measured and modeled $\mathrm{OH}$ in Sjostedt et al. (2007) can be explained by the presence of reactive bromine alone, based on our data from 2007/2008. However, during sporadic high $\mathrm{BrO}$ events a large impact of $\mathrm{BrO}$ on $\mathrm{HO}_{\mathrm{x}}$ chemistry can be expected (Liao et al., 2011b).

While the levels of $\mathrm{BrO}$ at Summit are low, they have sufficient impact on the oxidative capacity of the boundary layer that the chemistry of bromine in and over sun-lit snow deserves more attention. Additional observations of $\mathrm{BrO}$ are needed to establish if the Summit observations are representative for other remote, non-marine snow surfaces. BrO released from snow on the Greenland and Antarctic ice sheets could also be important as a source of reactive bromine in the free troposphere. As discussed above, the diurnal variation of the boundary layer height often leads to strong surface inversions at night, which decouple the daytime boundary layer from the surface. Because of the high altitudes of the ice sheets, this residual layer, and the inorganic bromine species in it, can mix into the free troposphere, providing a thus far unrecognized source of bromine.

Acknowledgements. The authors would like to thank all the members of the GSHOx campaign, the staff at Summit station for their support, and the NSF GEO ATM Tropospheric Chemistry program for funding (Grant ATM-0612279:002). Logistic support was provided by NSF OPP Arctic Research Support and Logistics program and $\mathrm{CH} 2 \mathrm{MHill}$ Polar Services. In addition, we extend thanks to the New York Air National Guard for the heavy airlift, and permission to conduct research at Summit granted by the Danish Polar Center and Greenland Home Rule.

Edited by: J. Kaiser

\section{References}

Barrie, L., Bottenheim, J., Schnell, R., Crutzen, P., and Rasmussen, R.: Ozone destruction and photochemical reactions at polar sunrise in the lower Arctic atmosphere, Nature, 334, 138-141, 1988.

Brooks, S., Moore, C., Lew, D., Lefer, B., Huey, G., and Tanner, D.: Temperature and sunlight controls of mercury oxidation and deposition atop the Greenland ice sheet, Atmos. Chem. Phys., 11, 8295-8306, doi:10.5194/acp-11-8295-2011, 2011 
Cantrell, C. A., Davidson, J. A., McDaniel, A. H., Shetter, R. E., and Calvert, J. G.: Temperature-dependent formaldehyde cross sections in the near-ultraviolet spectral region, J. Phys. Chem., 94, 3902-3908, doi:10.1021/j100373a008, 1990.

Chameides, W. L. and Davis, D. D.: Iodine: Its Possible Role in Tropospheric Photochemistry, J. Geophys. Res., 85, 7383-7398, 1980.

Colman, J. J., Swanson, A. L., Meinardi, S., Sive, B. C., Blake, D. R., Rowland, F. S.: Description of the analysis of a wide range of volatile organic compounds in whole air samples collected during PEM-Tropics A and B, J. Anal. Chem., 73, 3723 $3731,2001$.

Conway, T., Lang, P., and Masarie, K.: Atmospheric Carbon Dioxide Dry Air Mole Fractions from the NOAA ESRL Carbon Cycle Cooperative Global Air Sampling Network, 1968-2009, Version: 2010-09-08, available online at: ftp://ftp.cmdl.noaa.gov/ccg/co2/ flask/event/, 2010

Dibb, J. E., Ziemba, L. D., Luxford, J., and Beckman, P.: Bromide and other ions in the snow, firn air, and atmospheric boundary layer at Summit during GSHOX, Atmos. Chem. Phys., 10, 99319942, doi:10.5194/acp-10-9931-2010, 2010.

Fitzenberger, R., Bösch, H., Camy-Peyret, C., Chipperfield, M., Harder, H., Platt, U., Sinnhuber, B., Wagner, T., and Pfeilsticker, K.: First profile measurements of tropospheric BrO, Geophys. Res. Lett., 27, 2921-2924, 2000.

Fleischmann, O., Hartmann, M., Burrows, J. P., and Orphal, J.: New ultraviolet absorption cross-sections of $\mathrm{BrO}$ at atmospheric temperatures measured by time-windowing Fourier transform spectroscopy, J. Photochem. Photobio. A, 168, 117132, doi:10.1016/j.jphotochem.2004.03.026, 2004.

Greenblatt, G. D., Orlando, J. J., Burkholder, J. B., and Ravishankara, A. R.: Absorption measurements of oxygen between 330 and $1140 \mathrm{~nm}$, J. Geophys. Res., 95, 18577-18582, doi:10.1029/JD095iD11p18577, 1990.

Hausmann, M. and Platt, U.: Measurement of bromine oxide and ozone in the high Arctic during Polar Sunrise Experiment 1992, J. Geophys. Res., 99, 399-413, 1994.

Hebestreit, K., Stutz, J., Rosen, D., Matveiv, V., Peleg, M., Luria, M., and Platt, U.: DOAS measurements of tropospheric bromine oxide in mid-latitudes, Science, 283, 55-57, 1999.

Herbert, G. A., Green, E. R., Koenig, G. L., and Thaut, K. W.: Monitoring instrumentation for the continuous measurement and quality assurance of meteorological observations, NOAA Tech. Memo. ERL ARL-148, p. 44, 1986.

Hirdman, D., Burkhart, J. F., Sodemann, H., Eckhardt, S., Jefferson, A., Quinn, P. K., Sharma, S., Strom, J., and Stohl, A.: Longterm trends of black carbon and sulphate aerosol in the Arctic: changes in atmospheric transport and source region emissions, Atmos. Chem. Phys., 10, 9351-9368, doi:10.5194/acp-10-93512010, 2010

Kahl, J. D. W., Martinez, D. A., Kuhns, H., Davidson, C. I., Jaffrezo, J. L., and Harris, J. M.: Air mass trajectories to Summit, Greenland: A 44-year climatology and some episodic events, J. Geophys. Res., 102, 26861-26875, 1997.

Liao, J., Huey, L. G., Tanner, D. J., Brough, N., Brooks, S., Dibb, J. E., Stutz, J., Thomas, J. L., Lefer, B., Haman, C., and Gorham, $\mathrm{K}$.: Observations of hydroxyl and peroxy radicals and the impact of $\mathrm{BrO}$ at Summit, Greenland in 2007 and 2008, Atmos. Chem. Phys., 11, 8577-8591, doi:10.5194/acp-11-8577-2011, 2011.
Liao, J., Sihler, H., Huey, L. G., Neuman, J. A. Tanner, D. J., Friess, U., Platt, U., Flocke, F. M., Orlando, J. J., Shepson, P. B., Beine, H. J., Weinheimer, A. J., Sjostedt, S. J., Nowak, J. B., Knapp, D. J., Staebler, R. M., Zheng, W., Sander, R., Hall, S. R., and Ullmann, K., A comparison of Arctic BrO measurements by chemical ionization mass spectrometry and long path-differential optical absorption spectroscopy, J. Geophys. Res., 116, D00R02, doi:10.1029/2010JD014788, 2011.

Mefford, T.: Cooperative Institute for Research in Environmental Sciences (CIRES), University of Colorado at Boulder, and NOAA Earth System Research Laboratory (ESRL), Boulder, Colorado, USA, 2010.

Platt, U. and Stutz, J.: Differential Optical Absorption Spectroscopy: Principles and Applications, Springer, Berlin, Heidelberg, 597, doi:10.1007/978-3-540-75776-4, 2008.

Read, K. A., Mahajan, A. S., Carpenter, L. J., Evans, M. J., Faria, B. V. E., Heard, D. E., Hopkins, J. R., Lee, J. D., Moller, S. J., Lewis, A. C., Mendes, L., McQuaid, J. B., Oetjen, H., SaizLopez, A., Pilling, M. J., and Plane, J. M. C.: Extensive halogenmediated ozone destruction over the tropical Atlantic Ocean, Nature, 453, 1232-1235, doi:10.1038/nature07035, 2008.

Saiz-Lopez, A., Mahajan, A. S., Salmon, R., Bauguitte, S. J.B., Jones, A. E., Roscoe, H. K., and Plane, J. M. C.: Boundary layer halogens in coastal Antarctica., Science, 317, 348-51, doi:10.1126/science.1141408, 2007.

Osthoff, H. D., Roberts, J. M., Ravishankara, a. R., Williams, E. J., Lerner, B. M., Sommariva, R., Bates, T. S., Coffman, D., Quinn, P. K., Dibb, J. E., Stark, H., Burkholder, J. B., Talukdar, R. K., Meagher, J., Fehsenfeld, F. C., and Brown, S. S.: High levels of nitryl chloride in the polluted subtropical marine boundary layer, Nat.1 Geosci., 1, 324-328, doi:10.1038/ngeo177, 2008.

Peters, C., Pechtl, S., Stutz, J., Hebestreit, K., Hönninger, G., Heumann, K. G., Schwarz, A., Winterlik, J., and Platt, U.: Reactive and organic halogen species in three different European coastal environments, Atmos. Chem. Phys., 5, 3357-3375, doi:10.5194/acp-5-3357-2005, 2005

Saiz-Lopez, A., Plane, J. M. C., and Shillito, J. A.: Bromine oxide in the mid-latitude marine boundary layer, Geophys. Res. Lett., 31, 4-7, doi:10.1029/2003GL018956, 2004.

Salawitch, R. J., Canty, T., Kurosu, T., Chance, K., Liang, Q., da Silva, A., Pawson, S., Nielsen, J. E., Rodriguez, J. M., Bhartia, P. K., Liu, X., Huey, L. G., Liao, J., Stickel, R. E., Tanner, D. J., Dibb, J. E., Simpson, W. R., Donohoue, D., Weinheimer, a., Flocke, F., Knapp, D., Montzka, D., Neuman, J. a., Nowak, J. B., Ryerson, T. B., Oltmans, S., Blake, D. R., Atlas, E. L., Kinnison, D. E., Tilmes, S., Pan, L. L., Hendrick, F., Van Roozendael, M., Kreher, K., Johnston, P. V., Gao, R. S., Johnson, B., Bui, T. P., Chen, G., Pierce, R. B., Crawford, J. H., and Jacob, D. J.: A new interpretation of total column $\mathrm{BrO}$ during Arctic spring, Geophys. Res. Lett., 37, 1-9, doi:10.1029/2010GL043798, 2010.

Schroeder, W. H., Anlauf, K. G., Barrie, L. A., Lu, J. Y., Steffen, A., Schneeberger, D. R., and Berg, T.: Arctic springtime depletion of mercury, Nature, 394, 331-332, doi:10.1038/28530, 1998.

Sjostedt, S. J., Huey, L. G., Tanner, D. J., Peischl, J., Chen, G., Dibb, J. E., Lefer, B., Hutterli, M. A., Beyersdorf, A. J., Blake, N. J., Blake, D. R., Sueper, D., Ryerson, T., Burkhart, J., and Stohl, A.: Observations of hydroxyl and the sum of peroxy radicals at Summit, Greenland during summer 2003, Atmos. Environ., 41, 5122-5137, 2007 
Stohl, A., Eckhardt, S., Forster, C., James, P., Spichtinger, N., and Seibert, P.: A replacement for simple back trajectory calculations in the interpretation of atmospheric trace substance measurements, Atmos. Environ., 36, 4635-4648, doi:10.1016/S13522310(02)00416-8, 2002.

Stutz, J., Hebestreit, K., Alicke, B., and Platt, U.: Chemistry of halogen oxides in the troposphere: comparison of model calculations with recent field data, J. Atmos. Chem., 34, 65-85, 1999.

Stutz, J., Ackermann, R., Fast, J. D., and Barrie, L.: Atmospheric reactive chlorine and bromine at the Great Salt Lake, Utah, Geophys. Res. Lett., 29, 18.1-18.4, doi:10.1029/2002GL014812, 2002.

Swanson, A. L., Blake, N. J., Dibb, J. E., Albert, M. R., Blake, D. R., and Rowland, F. S.: Photochemically induced production of $\mathrm{CH}_{3} \mathrm{Br}, \mathrm{CH}_{3} \mathrm{I}, \mathrm{C}_{2} \mathrm{H}_{5} \mathrm{I}$, ethane, and propene within surface snow at Summit, Greenland, Amos. Environ., 36, 2671-2682, 2002.

Theys, N., Van Roozendael, M., Hendrick, F., Fayt, C., Hermans, C., Baray, J.-L., Goutail, F., Pommereau, J.-P., and De Maziére, M.: Retrieval of stratospheric and tropospheric $\mathrm{BrO}$ columns from multi-axis DOAS measurements at Reunion Island $\left(21^{\circ} \mathrm{S}\right.$, $56^{\circ}$ E), Atmos. Chem. Phys., 7, 4733-4749, doi:10.5194/acp-74733-2007, 2007.

Thomas, J. L., Stutz, J., Lefer, B., Huey, L. G., Toyota, K., Dibb, J. E., and von Glasow, R.: Modeling chemistry in and above snow at Summit, Greenland - Part 1: Model description and results, Atmos. Chem. Phys., 11, 4899-4914, doi:10.5194/acp-11-48992011, 2011a.

Thomas, J. L., Stutz, J., Dibb, J. E., Huey, L. G., Liao, J., Tanner, D., Lefer, B., and von Glasow, R.: Modeling halogen chemistry in and above snow at Summit, Greenland - Part 2: Radical chemistry and sensitivity studies, Atmos. Chem. Phys. Discuss., in preparation, $2011 \mathrm{~b}$.
Thornton, J. A., Kercher, J. P., Riedel, T. P., Wagner, N. L., Cozic, J., Holloway, J. S., Dubé, W. P., Wolfe, G. M., Quinn, P. K., Middlebrook, A. M., Alexander, B., and Brown, S. S.: A large atomic chlorine source inferred from mid-continental reactive nitrogen chemistry., Nature, 464, 271-274, doi:10.1038/nature08905, 2010.

Tuckermann, M., Ackermann, R., Golz, C., Lorenzen-Schmidt, H., Senne, T., Stutz, J., Trost, B., Unold, W., and Platt, U.: DOAS-observation of halogen radical-catalysed arctic boundary layer ozone destruction during the ARCTOC-campaigns 1995 and 1996 in Ny-Alesund, Spitsbergen, Tellus B, 49, 533-555, 1997.

von Glasow, R., von Kuhlmann, R., Lawrence, M. G., Platt, U., and Crutzen, P. J.: Impact of reactive bromine chemistry in the troposphere, Atmos. Chem. Phys., 4, 2481-2497, doi:10.5194/acp4-2481-2004, 2004.

Voigt, S., Orphal, J., Bogumil, K., and Burrows, J. P.: The temperature dependence $(203-293 \mathrm{~K})$ of the absorption cross sections of $\mathrm{O}_{3}$ in the $230-850 \mathrm{~nm}$ region measured by Fouriertransform spectroscopy, J. Photochem. Photobio. A, 143, 1-9, doi:10.1016/S1010-6030(01)00480-4, 2001.

von Glasow, R. and Crutzen, P. J.: Tropospheric Halogen Chemistry, Elsevier, Treatise on Geochemistry edn., 1-67, 2007.

Ziemba, L. D., Dibb, J. E., Griffin, R. J., Huey, L. G., and Beckman, P.: Observations of particle growth at a remote, Arctic site, Atmos. Environ., 44, 1649-1657, doi:10.1016/j.atmosenv.2010.01.032, 2010. 